\title{
Stability of Metal Carbonate in Soil by Ureolytic Bacteria under Simulated Acid Rain \\ DEEPIKA KUMARI ${ }^{1}$, XUEYAN CHEN ${ }^{2}$, VARENYAM $\mathrm{ACHAL}^{2 *}$ \\ ${ }^{1}$ College of Architecture and Urban Planning, Tongji University, Shanghai, China \\ ${ }^{2}$ Environmental Engineering Program, Guangdong Technion \\ - Israel Institute of Technology, Shantou, China \\ (*correspondence: varenyam.achal@gtiit.edu.cn)
}

Microbially induced carbonate precipitation (MICP), a type of biomineralization, provides effective immobilization for metals. The process of MICP is governed by ureolytic bacteria where bacterial cells produce enzyme urease that hydrolyes urea into amoonium and carbonate ions. Finally, chemical reaction occurs between carbonate and calcium ions present on the cell wall of bacterial cells, resulting into the precipitation of calcium carbonate. However, the stability of such carbonated compound during biomineralization is a matter of concern, specially under acid rain.

Thus, in one of studies, research was aimed to study the stability of major compound, calcium carbonate, of MICP in soil under simulated acid rain (SAR). The SAR treatments were initiated in soil by spraying the soil pots with water of four $\mathrm{pH}$ levels: $3.5,4.5,5.5$, and 7.0, continuously for two months. In order to confirm the stability of cacium carbonate, biostimulation was adopted to accelerate growth of ureolytic bacteria in soil during SAR to carryout MICP. The nutrient broth containing urea and calcium chloride was used as biostimulating media [1]. At the end of treatments, soil samples were collected from different layers of pots and were analyzed by high-throughput sequencing for bacterial community composition. The higher quantity of urease in soil represented the presence of significant number of ureolytic bacteria and their activities. Several ureolytic bacteria including of Arthrobacter and Sporosarcina genera were associated with SAR treated soils at all pHs. Fourier Transform-Infra Red (FTIR) spectroscopy and X-Ray Diffraction (XRD) identified functional chemical groups and major compounds related to calcium carbonate precipitation that showed its stability even when $\mathrm{pH}$ was as low as 3.5. The results are helpful in drawing conclusion that heavy metals co-precipitated during MICP tend to be immobilized in soil rather than released under acid rain.

[1] Chen X, Achal V (2019) Biostimulation of carbonate precipitation process in soil for copper immobilization. Journal of Hazardous Materials 368, 705-713. 